\title{
Идеал чиновника и российская действительность начала XIX века в записках Р. М. Цебрикова
}

The image of an ideal buraucrat and the early 19TH century russian reality in the memoirs of $R$. M. Tzebrikov

\section{STRESZCZENIE:}

Artykuł analizuje pamiętniki znanego rosyjskiego tłumacza, pisarz i muzykologa Romana Maksymowicza Cebrikowa (1763-1817). Jego wspomnienia przedstawiają podróż odbytą z Sankt Petersburga do Charkowa zimą lat 1813-1814. Cebrikow kreuje w nich obraz idealnego urzędnika w realiach prowincji rosyjskiej początku XIX wieku.

Słowa kluczowe: R. M. Cebrikow, pamiętniki, wojna 1812 roku, Charków

В 1790 г. было опубликовано «Путешествие из Петербурга в Москву» А. Н. Радищева, а через полтора десятка лет той же дорогой, но далее, через Москву на Харьков, проехал известный российский переводчик, писатель, музыковед Роман Максимович Цебриков. По возвращении к месту службы в Петербург Р. М. Цебриков записал свои впечатления от этой поездки в форме письма к старинному другу, проживающему в Киеве. По своей жанровой природе, содержанию и общему настроению записки Р. М. Цебрикова абсодютно несхожи с «Путешествием» «бунтовщика» А. Н. Радищева, но двух авторов роднит критическое отношение к российской действительности, а также схожий жизненный опыт - оба закончили Дейпцигский университет, служили в раздичных ведомствах, занимались литературной деятельностью, к тому же, по предположению ряда исследователей, были дично знакомы ${ }^{1}$.

${ }^{1}$ М. А. Арзуманова, Цебриков Роман Максимович, [w:] Словарь русских писателей 
Роман Цебриков родился 1/12 октября 1763 г. в Харькове в семье старшины казачьего полка Михаила Трофимовича и Зиновии Андреевны Цебриковых. В 1765 г. отец умер, и на попечении матери остадись сыновья Иван и Роман и младшая дочь. Семья жила бедно, но через несколько лет Иван поступил на службу в канцелярию губернатора и вскоре был приближен к губернатору Слободско-Украинской губернии Е. А. Щербинину².

В 1773 г. Ивану Цебрикову удалось устроить младшего брата в «прибавочные классы» при Харьковском колиегиуме. Окончив их с отличием, Роман переехал в Киев, к Ивану Цебрикову, который с 1775 г. служил в канцелярии генерал-губернатора Малороссии и президента Второй Малороссийской коллегии фельдмаршала П. А. Румянцева-Задунайского. Иван Цебриков мечтал отправить младшего брата для продолжения обучения за границу. Местом обучения был выбран университет Дейпцига, где Р. М. Цебриков изучал богословие, философию, юриспруденцию, статистику, математику, физику, естествознание, греческий, латинский и древнееврейский языки, совершенствовался в немецком и французском языках 3.

В 1785 г. Цебриков окончил курс наук «с похвальным аттестатом» и, мечтая послужить Отечеству, приехал в Санкт-Петербург, минуя $\mathrm{Харьков}^{4}$. Однако уже первые месяцы пребывания в России принесли разочарование: не застав президента Коммерц-коллегии графа А. Р. Воронцова, к которому у него были рекомендательные письма, Р. М. Цебриков с большим трудом устроился на службу в Колиегию иностранных дел актуариусом с годовым жалованием в 120 руб., в то время как «мальчики лет 12, имея выше ... чины, получали жалованье по 300 руб., едва писать умея». Такое «пристрастное раздавание чинов и денег дало ему понятие о связях между собою фамидий и породило в нем презрение к ним, так что во всю свою службу не просил и не добивался ни о чинах, крестах и прибавках жалованья» ${ }^{5}$.

Переломным этапом в жизни Р. М. Цебрикова стала русско-турецкая война 1787-1791 гг. В 1787 г. он был назначен сопровождать грузинского посланника к фельдмаршалу Г. А. Потемкину. По при-

18 в., wyd. 3, Санкт Петербург 2010; А. Г. Татаринцев, Прототипь героев «Путешествия из Петербурга в Москву» А. Н. Радищева, „Русская литература”, 1972, nr 1, s. 87-94.

${ }^{2}$ Отдел Рукописей Российской Национальной Библиотеки (ОРРНБ), фонд 830, том 1, k. $135 \mathrm{v}$.

${ }^{3}$ Ibidem, k. 135v-136v; Р. М. Цебриков, Описание двухлетней петербургской жизни, [w:] От Лейпцига до Очакова. Дневниковые записки Р. М. Цебрикова. 1785-1788, pod red. С. А. Коздова, Санкт Петербург 2009, s. 85.

${ }^{4}$ P. М. Цебриков, op.cit., s. 82.

${ }^{5}$ ОРРНБ, фонд 830, том 1, k. 137. 
бытии на место Роман Максимович поступил на службу к светлейшему князю «для исправления дел» по Иностранной секретной экспедиции, принимал участие во взятии Очакова, Аккермана и Бендер.

В дальнейшем Р. М. Цебриков состоял при миссии чрезвычайного и полномочного посла графа Я. Е. Сиверса в Речи Посполитой, служил в секретной экспедиции Министерства внутренних дел, с 1810 г. и до самой смерти состоял помощником начальника III Отделения в Комиссии для составления законов. Одновременно с 1808 г. по 1813 г. Роман Максимович был личным переводчиком Александpa I. Р. М. Цебриков дослужился до чина действительного статского советника, имел многочисленные награды

Р. М. Цебриков состоял в родстве с драматургом Я. Б. Княжниным, среди его друзей и знакомых были писатели Н. М. Карамзин и Д. И. Фонвизин, драматург и актер П. А. Плавильщиков, экономист и публицист Ф.-Х. Вирст, путешественник И. Ф. Крузенштерн, композитор Д. С. Бортнянский и др. ${ }^{7}$

Роман Максимович был автором многочисленных переводов философских, юридических, исторических и других трудов, а также оригинальных работ по истории, литературе, музыке и эстетике. Значительная часть оригинального иитературного наследия Р. М. Цебрикова не была опубликована. Особое внимание современные исследователи обращают на статью «Адская политика владетелей тиранов и кроткое им напоминовение человеколюбца», в которой автор выступает как противник самодержавного правления 8 .

Кроме всего прочего, в его бумагах сохранилось «Письмо к старинному моему приятелю и бывшему некогда соученику, после долговременной службы в С. П. Б. удалившемуся в Киев на жительство и для препровождения остальных дней своей жизни, о поездке моей из С. П. Б. в Х[арьков] для свидания с родным братом моим, не видавшись с ним двадцать два года». Исследователь С. А. Коздов видит ценность этого сочинения в многочисленных бытовых зарисовках 9 , однако повествование о поездке из столицы в небольшой провинциальный город содержит гораздо более серьезный и многоаспектный материал, трактуя который, следует учитывать тот факт, что Р. М. Цебриков

${ }^{6}$ Ibidem, k. 138v-139v.

${ }^{7}$ Ibidem, k. 139v.

${ }^{8}$ М. А. Арзуманова, ор.cit., s. 36-41; С. А. Козлов, Мир и война, долг и свобода в восприятии писателя и переводчка Романа Цебрикова, [w:] От Аейпцุига до Очакова. Дневниковые записки Р. М. Цебрикова. 1785-1788, Санкт Петербург 2009, s. 39-40.

${ }^{9}$ C. A. Коздов, op.cit., s. $39-40$. 
был не просто знаком с радищевским «Путешествием», но, возможно, стал прототипом одного из его героев ${ }^{10}$. В очерке «Подберезье» Радищев описывает встречу с новгородским семинаристом, который обнаруживает знание нескольких языков и знакомство с античной и новейшей дитературой и совсем не по-семинаристски рассуждает о просвещении. Автор с сочувствием относится к убеждению «семинариста» в необходимости реформирования системы образования в России, но не разделяет его увлечения масонством. По мнению А. Г. Татаринцева, в образе семинариста перед читателями предстает воспитанник Дейпцигского университета Р. М. Цебриков. В подьзу этого говорят как уровень образования последнего, так и его знакомство масонскими сочинениями, которые он использовал в своих трудах ${ }^{11}$. Внучка Р. М. Цебрикова, писательница и публицист М. К. Цебрикова схожим образом характеризовала взгляды своего деда ${ }^{12}$.

Глава «Подберезье» была написана, когда Р. М. Цебрикову было около 25 лет $^{13}$. Путешествие из Петербурга в Харьков и обратно состоялось в декабре 1813-январе 1814 г., за три года до его смерти, поэтому текст воспоминаний аккумулирует в себе весь жизненный опыт автора. Повидав мир, пережив крушение надежд и смерть жены, Р. М. Цебриков возвращается в город своего детства, чтобы встретиться со старшим братом Иваном Максимовичем, который также потерял супругу и, по словам мемуариста, «заклинал меня приехать к нему в последний раз повидаться в сей бренной жизни, разделить с ним, среди семейства его, общую горесть нашу» ${ }^{14}$.

Роман Максимович принялся за написание мемуаров сразу же по возвращении в Петербург. Приступая к описанию своего путешествия, Р. М. Цебриков отмечает, что во время поездки он ничего «достойного любопытства» не записывал. Опираясь исключительно на свою память, Роман Максимович опасается, что «описание мое будет походить на тело без души, на скелет сущий» ${ }^{15}$. Впрочем, знакомство с текстом и условиями его создания позволяет не принимать во внимание жалобы автора на память. На протяжении всего повествования

${ }^{10}$ А. Г. Татаринцев, ор.cit., s. 92; Г. Шторм, Потаенный Радищев: Вторая жизнь «Путешествия из Петербурга в Москву», wyd. 2 uzupełnione i poprawione, Москва 1968.

${ }^{11}$ А. Г. Татаринцев, ор.cit.

${ }_{12}$ М. К. Цебрикова, Русский человек. Из воспоминаний, „Современник”, ks. 7, 1911, s. $152-154$.

${ }^{13}$ А. Г. Татаринцев, op.cit., s. 96.

${ }^{14}$ Центральний Державний Історичний Архів України, м. Київ (ЦДІАК), фонд 2040 , опис 1 , справа 45, k. $4 \mathrm{v}$.

${ }^{15}$ Ibidem, k. 2-2v, 40v. 
Р. М. Цебриков скрупулезно воспроизводит не только все виденное и слышанное, но также продуманное и прочувствованное.

Путь из Петербурга до Харькова лежал через Москву, поэтому в начале своего путешествия Р. М. Цебриков географически следует за А. Н. Радищивым, однако в дитературном отношении он самостоятелен. Первые страницы его мемуарных записок посвящены описанию интересных, на его взгляд, мест и встреч, но о чем бы ни писал Цебриков, в его рассказ постоянно вторгается война. Роман Максимович задается вопросом: «От чего происходят наши кровопродитные брани? Когда мы все суть человеки, все - чада единого премилосердного Отца небесного; ... все мы знаем преважное и спасительное предписание библейское: «Не убей»; и убиваем, однако без содрогания и зазрения совести тысячи себе подобных, разумом одаренных тварей...?» $\gg^{16}$ В конце концов, «пересчитавши все известные ... политические причины ... войны наступательной, предупредительной, или даже и оборонительной», автор находит их главного виновника - «честодюбивого властелина», который завидует богатству и процветанию «соседа своего благоденствующего» ${ }^{17}$.

По мере удаления от Петербурга, образ войны становится все более реальным и, наконец, перед путешественником предстает Москва - «разоренная, опустошенная, выжженная» ${ }^{18}$. Следует отметить, что война 1812 г. серьезно повлияла на взгляды Р. М. Цебрикова: в записках мы не встретим того «оттенка водьтерианства», о котором говорит М. К. Цебрикова. Более того, автор откровенно недолюбливает все французское, и в дальнейшем во всех встреченных им французах видит шпионов ${ }^{19}$.

За Москвой тяготы дадьнего путешествия усидиваются: повсюду их встречают грязные хаты, дороговизна ночлега и еды, отсутствие лошадей на почтовых станциях. Р. М. Цебриков удичает почтовых смотрителей в подделке книг для записей подорожных с целью получения денег от водьных ямщиков и с горечью отмечает «воровство казенного интереса» ${ }^{20}$. Постепенно рассказ наполняется все большим кодичеством сюжетов о злоупотреблениях и бездеятельности властей разного уровня. Так, зима 1813-1814 г. была отмечена жестокими морозами и большим снегом, что из-за отсутствия каких-дибо дорожных знаков зачастую приводило к гибели путников. Оплаки-

\footnotetext{
${ }^{16}$ Ibidem, k. 10.

${ }^{17}$ Ibidem, k. 12.

${ }^{18}$ Ibidem, k. 27v-28.

${ }^{19}$ Ibidem, k. 66v-69.

${ }^{20}$ Ibidem, k. 31-31v, 36.
} 
вая многочисленные жертвы стихии, мемуарист задается вопросом: «Неужели души их [губернаторов - В. И.] не чувствуют, что они были и суть виновники, ничем неизвиняемые, дютой смерти несчастных поселян, и всех путешествующих во время ужасных вьюг по занесенным, глубоким снегам, проезжим дорогам, никакими приметами необозначенным в губерниях, попечению и надзору их вверенных от монарха...?» ${ }^{21}$.

Наконец, во второй день Рождества Роман Максимович достигает Харькова. С большой теплотой мемуарист рассказывает о встрече с братом и его семьей. За то короткое время, что Р. М. Цебриков пробыл в Харькове (около двух недель), братья нечасто оставались наедине, но даже те немногие строки, которые посвящены семейной жизни автора, позволяют говорить не только о родственных, но и дружеских отношениях между Иваном Максимовичем и Романом Максимовичем Цебриковыми.

Отметим, что именно характеризуя своего брата, Роман Максимович говорит и о собственных убеждениях. Когда в один из вечеров Цебриковы начали обсуждать обстоятельства своей жизни, прежде всего, они вознесли «искреннее и усердное благодарение Творцу всевышнему за все ... ниспослание на нас благодати, руководствовавшей деяниями нашими, никогда чести нашей не запятнавшими», далее, посмеиваясь над своими «значущими» чинами отметили свое нежелание угождать начальству, нетерпимое отношение ко всякого рода «подношениям» и добросовестное отношение к своему делу ${ }^{22}$. Повидимому, данный вопрос был для автора крайне важен, поскольку подобные характеристики он вкладывает также в уста других героев. Так, некие знакомые («коллежские ассесоры» и «надворные советники») говорят Р. М. Цебрикову, что слышали о нем, как о человеке независимом: «что вы как о чинах, так и об орденах нимало не заботитесь, а получаете их, когда вашим начадьникам вздумается их вам дать»; «что вы не искательны и только любите дома заниматься книгами» ${ }^{23}$. Схожим образом аттестуют И. М. Цебрикова отставной артиллерийский генерал, по словам которого «ежели бы у всех их в совести недрилась справедливость, и правосудие было бы соблюдаемо ими так, как соблюдает оное Ц[ебриков], тогда бы в наших архивах было мараной бумаги тремя четвертями меньше, и споры, и тяжбы в той же пропорции уменьшидись», и вице-губернатор В.Г. Муратов, который

\footnotetext{
${ }^{21}$ Ibidem, k. 33v-38, 42.

${ }^{22}$ ЦДІАК, фонд 2040, опис 1, справа 99, k. 12-12v.

${ }^{23}$ Ibidem, k. 50-50v.
} 
«не преминул ... выхвалить и брата моего службу долговременную, усердную, ревностную, честную и беспорочную» ${ }^{24}$. При этом «чиновники добрые, честные, право-правящие, правду любящие, к службе государевой ревностные и усердные» никаких наград не имеют, а по службе зачастую продвигаются «одними происками» «совсем неученые и неопытные» ${ }^{25}$.

Несомненно, что подобные убеждения мемуариста переносятся на всех его «героев» (местных чиновников, университетских профессоров, представителей духовенства и купечества): насколько они соответствуют или не соответствуют выстраданному автором «идеалу», тем более что во время многочисленных визитов ему предоставляется богатый материал для размышлений. Как отметил в один из вечеров Р. М. Цебриков, «во всю жизнь мою, когда я был гораздо моложе, никогда и в самом Петербурге не развозил столько визитов» ${ }^{26}$.

В среде местного чиновничества безусдовно одобритедьного отзыва заслужили два губернских деятеля: секретарь казенной палаты надворный советник К..., «человек ученый, и притом ловкой», который приходился Цебриковым племянником, а также «неутомимый в делах» губернский казначей Р..., любимый за исправность «прежними генерал-прокурорами» ${ }^{27}$. Последнему не раз предлагали службу в Петербурге, но он «по любви к простой философской жизни и приверженности к своей родине не променял своего города на стодицу». Визит к губернскому казначею, во время которого обсуждалось экономическое положение губернии, по признанию мемуариста, «был для меня самый приятный и самый поучительный» 28 .

Ряд чиновников признавались весьма деятельными и относительно честными, как «весьма сведущий в делах» губернский прокурор Дюбовников, который «не желая сквернить рук своих взятками непозволенными» занимался покупкой и продажей лошадей, что позволяло ему жить безбедно ${ }^{29}$, но большинство представителей губернских властей были осуждены мемуаристом за тщеславие, карьеризм, взяточничество и бездеятельность.

Тщеславием чиновники не уступали местной знати: сначала Р. М. Цебрикова поразила запряженная цугом карета одного из богатейших помещиков Харьковской губернии генерала О. И. Хорвата,

\footnotetext{
${ }^{24}$ Ibidem, k. 52-52v, 56.

${ }^{25}$ Ibidem, k. 7v-8.

${ }^{26}$ Ibidem, k. 10v-11v.

${ }^{27}$ Ibidem, k. 53.

${ }^{28}$ Ibidem, k. $7 \mathrm{v}-8$.

${ }^{29}$ ЦДІАК, фонд 2040, опис 1., справа 45, k. 56.
} 
но затем он с удивлением отметил, что подобным образом передвигаются по городу вице-губернатор В. Г. Муратов и председатель уголовной палаты Ю. Ф. Минстер 30 .

Однако подобные проявления ненужной расточитедьности довольно быстро меркнут перед лицом того беззакония и произвола, олицетворением которого, по мнению автора, был губернатор И. И. Бахтин. Образ, созданный Р. М. Цебриковым, диссонирует и с мемуарной, и с историографической традицией, которые рисуют умного, деятельного, образованного и просвещенного администратора, пользовавшегося доверием императора Александра I⒈ Р. М. Цебриков изобразил общее недовольство харьковчан грубым, малообразованным, нерадивым губернатором. Среди прочего, он предложил свою трактовку известной истории, когда представители дворянского и купеческого сословия преподнесли в дар И. И. Бахтину шестьдесят тысяч рублей, которые и были приняты губернатором с дозволения Александра I. По уверениям одного из информантов Р. М. Цебрикова, добровольное согласие на этот дар дали только немногие особы, остальные же считали сей «побор» неуместным и противозаконным, что же касается дозволения государя, то его исходатайствовали покровители и «милостивцы» И. И. Бахтина ${ }^{32}$. Далее, иллюстрируя крутой и суровый нрав губернатора, мемуарист рассказывает об одной из жертв его своеволия - советнике губернского правления Звереве, который в результате неудачного комплимента губернаторше был уволен со службы, под влиянием чего заболел и вскоре умер 33 . При этом мемуарист дает понять, что таких жертв значительно больше: когда И. И. Бахтин заболел, брат мемуариста заметил, что благодаря этому событию «мы успеем освободить многих из тюрьмы, кои содержаться в оной или совсем понапрасну, или по нерадению нашего начальника» ${ }^{34}$.

Мемуарист отказывает И. И. Бахтину в каких-либо способностях, и все его успехи связывает с женой, Д. И. Бахтиной. Отдавая должное ее уму и хитрости, Р. М. Цебриков указывает на первостепенную роль Дарьи Ивановны в назначении мужа губернатором, отмечает ее зна-

${ }^{30}$ Ibidem, k. 56-57v.

31 А. И. Багалей, А. П. Миллер, История города Харькова за 250 лет его существования (1655-1905), t. 2, ХІХ-начало ХХ в., Харьков 1993, s. 185-187; А. С. Шуринов, Иван Иванович Бахтин (1756-1818) - государственный деятель и поэт - доверенное лицо Александра I. http://forums.vif2.ru. (dostęp: 10.09.2014).

32 ЦДІАК, фонд 2040, опис 1., справа 45, k. 59v-60.

${ }^{33}$ ЦДІАК, фонд 2040, опис 1., справа 99, к. 9, 29.

${ }^{34}$ Ibidem, k. 11v. 
читедьное вдияние на мужа, а также намекает на не безвозмездное посредничество последней при решении раздичных тяжб ${ }^{35}$.

В изображении Р. М. Цебрикова под стать губернатору оказываются и многие его помощники: не вызывает симпатии вице-губернатор В.Г. Муратов, «краснобай, низкопоклонец», который дюбит рассказывать о «своих подитических подвигах» в Петербурге; гостеприимный и веседый председатель уголовной палаты Ю. Ф. Минстер покровитедьствует проституции; местный городничий под покровительством губернатора берет взятки и вершит «пристрастные» розыски и «присуждения» ${ }^{36}$.

Таким образом, здоупотребления становятся одной из кдючевых тем «письма» Р. М. Цебрикова. Мемуарист скрупулезно фиксирует все «прегрешения» местных властей: обман жителей, жертвовавших своих лошадей для армии; чрезвычайное обогащение чиновников, состоящих в рекрутской комиссии; растрату казенных денег при осушении улиц и постройке мостов; «нерадение градоправительства» о чистоте города; случившуюся по вине чиновников Валковскую трагедию и т. д. ${ }^{37}$ Эти здоупотребления не ограничены автором географически, они, по его мнению, царят повсюду. Расспрашивая своего старинного приятеля, который приехал повидаться с Р. М. Цебриковым из Воронежа, о последних новостях, он узнает о крупных хищениях, в которых замешан воронежский вице-губернатор, что позволяет с горечью заметить: «таковые по управлению злоупотребления оказались в сие время во многих местах России, в такое именно время, когда разгневанная судьба удручала и карала всех ее обитателей то естественными, то нравственными здами» ${ }^{38}$.

Рассказ мемуариста обрывается на событиях, связанных с возвращением из Харькова в Петербург. Вероятнее всего, воспоминания не были закончены вследствие скоропостижной смерти автора 3 февраля 1817 г., но возможно, мы имеем дело с неподными копиями: «Письмо...» Р. М. Цебрикова дошло до нас в незаконченном виде в двух списках: один хранится в ЦГИАК Украины ${ }^{39}$, другой в Отделе рукописей Российской национальной библиотеки ${ }^{40}$. Как указывает М. К. Цебрикова, когда Роман Максимович умер, «еще не успеди обрядить его, как явился адъютант Александра I и, обыскав

\footnotetext{
${ }^{35}$ ЦДІАК України, фонд 2040, опис 1., справа 45, k. 56-59v.

${ }^{36}$ Ibidem, k. 52v; справа 99, k. 21v, 33v-34.

${ }^{37}$ ЦДІАК України, фонд 2040, опис 1., справа 99, k. 18-21v.

${ }^{38}$ Ibidem, k. 18-18v.

${ }^{39}$ ЦДІАК України, фонд 2040, опис 1., справа 45 і 99.

${ }^{40}$ ОРРНБ, фонд 830, том 1.
} 
все ящики письменного стола, забрал все бумаги, кроме малозначущих тетрадей, увез все показать императору. Дед мой вел записки и дневник. Ничто не было возвращено наследникам» ${ }^{41}$. Оставшиеся бумаги М. К. Цебрикова в 1889 г. передала в дар Императорской публичной библиотеке (теперь - Российская национальная библиотека, Санкт-Петербург $)^{42}$.

Таким образом, мемуарные записки, обозначенные Р. М. Цебриковым как «письмо» и написанные в форме путевых заметок, имеют сложную жанровую природу: наряду с описанием тех мест, в которых побывал автор, и состоявшихся там встреч, они знакомят читателя с внутренним миром мемуариста, его взглядами и убеждениями относительно многих вопросов, которые волновали его современников. Безусловно, одна из центральных тем, которая соединяет воедино многие сюжеты - это «здоупотребления» властей, которыми, по его мнению, пронизана вся российская действительность. В этом прототип радищевского «Путешествия» сближается с бессмертным автором этого произведения.

\section{BIBLIOGRAFIA:}

Арзуманова М. А., Цебриков Роман Максимович, [w:] Словарь русских писателей 18 в., wyd. 3, Санкт Петербург 2010.

Багалей Д. И., Миллер Д. П., История города Харькова за 250 лет его существования (1655-1905), t. 2, ХІХ-начало ХХ в., Харьков 1993.

Козлов С. А., Мир и война, долг и свобода в восприятии писателя и переводика Романа Цебрикова, [w:] От Иейпцица до Очакова. Дневниковые записки Р. М. Цебрикова. 1785-1788, Санкт Петербург 2009.

Татаринцев А. Г., Прототипь героев «Путешествия из Петербурга в Москву» А. Н. Радищева, „Русская литература”, 1972, nr 1.

Цебрикова М. К., Русский человек. Из воспоминаний, „Современник”, ks. 7, 1911.

Цебриков Р. М., Описание двухлетней петербургской жизни, [w:] От Аейпцица до Очакова. Дневниковые записки Р. М. Цебрикова. 1785-1788, pod red. С. А. Козлова, Санкт Петербург 2009.

Шторм Г., Потаенный Радищев: Вторая жизнь «Путешествия из Петербурга в Москву», wyd. 2 uzupełnione i poprawione, Москва 1968.

Шуринов А. С., Иван Иванович Бахтин (1756-1818) - государственный деятель и поэт доверенное лицьо Александра I. http://forums.vif2.ru.

\footnotetext{
${ }^{41}$ М. К. Цебриков, op.cit., s. 154.

${ }^{42}$ Отчет Императорской публиной библиотеки за 1889 год, С.-Петербург 1893, s. 86-91.
} 


\section{ABSTRACT:}

The paper presents a research into the memories of the famous Russian translator, writer, and musicologist Roman Maksimovich Tsebrikov (1763-1817). In his memoirs about a journey taken from Petersburg to Kharkov in the winter of 1813-1814 Tsebrikov created the image of an ideal bureaucrat colliding the Russian reality at the beginning of the 19 th century.

Key words: R. M. Tsebrikov, memoirs, the war in 1812, Kharkiv Province.

\section{NOTA O AUTORZE:}

Viktoriya Ivashchenko - kandydat nauk historycznych, docent Katedry Historiografii, Źródłoznawstwa i Archeologii Charkowskiego Uniwersytetu Narodowego im. W. N. Karazina, dyrektor Muzeum Historii Charkowskiego Uniwersytetu Narodowego im. W. N. Karazina. 